DOI: $10.17148 /$ IARJSET.2021.8975

\title{
Identifying the structure skill development and Training for Youth in Automotive Industry (A CSR Activity To overcome the Employability challenges)
}

\author{
Dr B.G. Karad ${ }^{1}$, Ms. Sarojini R Pandit ${ }^{2}$ \\ Principal, Professor \& Research Guide Dept of Commerce. Shri Siddheshwar Mahavidyalya Majalgaon \\ ( DistBeed) (Maharashtra $)^{1}$
}

Research Scholar (Department of Management Science). Affiliation -Dr Babasaheb Ambedkar Marthwada University

Aurangabad (Maharashtra) ${ }^{2}$

\begin{abstract}
India has diverse manpower field to support industries and manufacturing sector, today are facing major challenges in skill development. Country like India is developing and evolving as a high capacity manufacturing automotivesector in global market. India is recognised as one of the youngest nation in the world by 2020 .The average Indian work force is below 30 years of age, Which is lower than any other manufacturing sector as it is observed with any other country like china ,Europe, US and Japan Now India has become second most populous country of the world the distinctive quality about the workforce in India abundance of human resources always attracted for competitive advantages for investment in manufacturing sector. In condition like India automotive sector is known as mass manufacturing sector which is already establish itself as leading manufacturing sector in employing skilled workforce. But more challenges are coming up in this sector that is huge manpower turnover, lack of skill training, this leads to quality inconstancy and simultaneously created threatening situation as a result of this Indian manufacturing is facing major hurdle to emerging as global manufacturing hub

Now this issue raised by automotive cluster How to face the challenges to overcome with this problem? Continues education for technically qualified youth is a strength of country but there should be systematically arrangework station training, structure up-skilling to provide a holistic understanding of overall manufacturing in terms of technology various other factors which is related to Quality, process engineering, safety etc. . This research paper study also help for understanding robust evaluation and deployment process which is needed to bridge the vast skill Gap in present industry situation.
\end{abstract}

Key words : Employability, Skill development, process constancy, role of industry cluster ,CSR .

\subsection{INTRODUCTION}

In India diverse manpower field support industries India's economy has surpassed in terms of growth rate and has emerged as fastest growing among the major economies of the world . several competitive advantages, India is fast evolving hub. Human recourses is strongly supporting industrial activities which provides competitive advantages to attract investments in the manufacturing sector, there is a mass manufacturing in automotive sector which is settle down as a one of the leading sectors in employing skilled workforce. As forecasted 291 million skilled workers are needed by the year 2022 , if India wants to become a globally leading manufacturing economy it has to step for skilled human recourses by 2022. Indian automotive sector give wide opportunity for Direct and indirect employment this sector itself would reach 38 million ( KPMG sector skill gap study ), but in India on the contrary lowest proportion of trained youth in the world high unemployment among the youth in combination of low skill availability.

Today demand of industry in mostly in terms of skilled work force is met by the government Institute which are in most instances not effectively run to provide an industry fit skilled work force even the courses are not timely updated along with technological advancement and as implemented at manufacturing plants. There is sudden crop up of increasing number of engineering colleges came up across India with doubtful quality of education standards most of those institutes are just churning out technical graduates who are not fit for industry . Although there is increasing number of privately run engineering colleges the number of private institutes providing skilled based education in diploma /ITI is limited . 
DOI: 10.17148/IARJSET.2021.8975

\subsection{Objectives of the study}

1) There is huge Gap in terms of availability of right skills

2) How we can reduce this inconstancy / imperfection in productivity due to skilled based activity .

3) Role of private industries to develop a structure and dynamic skill development

4) CSR end over to provide better opportunity to youth to reduce unemployment.

\subsection{Skill development in Youth}

Skills has to be defined in the combination of personal attributes, as a set of Achievements, understanding and that makes individual more likely to gain employment and to be successful in their occupation. Both soft skills and hard skills to be defined in each type of education which gives the inventory of various types of skills set for further occupation so that individual become multitasking and multi skilled. Technical skills can be defined at earlier stage of education so that individual can be groomed accordingly to its ability

\subsection{Present situation to cope up with unemployment.}

Though India had good scope of education system, but lack of skilled manpower in industry for higher education industry has taken efforts for bridging this Gap from time to time. In largest technology government had made lot of facilities for primary education government is also taking efforts to improve technical education skilled workers are short in supply . the ministry of human recourses developments governs the education and vocational education in India but many times this schemes remain failure it won't reach to grass root level All India technical education (AICTE) and UGC focuses on colleges education that is provided through technical board now role of Private industry and institutes highlights to eradicate the chronic problem of our country that is technical education and skill development of various class of students. Inconstancy in manufacturing process and shortage of skilled manpower relates to manpower turnover and rejection of productivity which again turns to training of new manpower this lead to failure of customer complaint also lead to many other problems.

\section{2) LITERATURE REVIEW.}

Skill development is a key driver to address poverty reduction in customer complaint is a key driver to increase productivity. Employability can be improved while increasing skill level vis vis reduce poverty the sustainable enterprise development will be observe in inclusive growth. Isyaku (2000) mentioned that the process of training and development is a continuous one , so many avenues open to acquire more new knowledge and develop the further skills and technique to make impact of it and function effectively. Training and development aim at improving competencies such as technical human conceptual and managerial for the furtherance of individual and organization growth

( Oribabor) 2000.

Skill gap is primary concern for companies to bridge this they are making huge investments in training to prepare employees for future needs as mentioned by Armstrong(2001). Training is a systematic development of knowledge, skills and attitude required by an individual to perform adequately a given task or job "the researchers and practitioners have constantly emphasized the importance of training due to its role and investment (Tan ,Boyce, 2003). Updating of the technical and vocational

Training curriculum for technological advancement and as implemented at the industry is a key to develop and industry fit work force bates \&davis(2010).skilled workers are short supply in India major investment in employee development pays off because it help ensure the quality of work force (cappelli etal 2010) several Indian automotive companies and bigger tier 1 Auto component suppliers have their training set up and they provide specialized training to the recruits as well as refresher courses to the existing workforce to stay productive . but the small and medium scale ancillaries of Auto sectors of auto sectors investing heavily in internal skill development infra structure remain a challenges . hence the existing vocational educational institutions have to be upgraded and additional ones should be started and industry should come forward in collaborating in meaning ful way towards supporting the academia in bridging the skill divide. lack of industry specific skills is the most severe in employment creating sectors such as manufacturing soft ware and automobiles( Mehrotra 2014 ).A multi stake holder partner ship involving the public and private sectors , community and other stake holders is needed. there is a need for technical and vocational training education training (TVET) act to support technical and vocational training system and open new path ways for implementations to generate employment (majumdar 2016) The CSR should be implemented in the concrete practice of human resource management for promoting employment (Ding 2010 ) on which this research paper focuses on through structure skill development . 


\section{3) METHOD AND APPROACH}

Few manufacturing industries in Maharashtra are implementing various projects to reduce such problems of unemployability .since this would contribute to the long team sustainability of the industry in terms of getting the rightly skilled manpower some observations are done in various industries how technical flaws can make impact on productivity the plant functions to identify and analyze the underlying factors some brain storming activity is done at multiple levels involving the shop floor workers, line managers, operators, supervisors thus a cause and effect analysis is slightly put the picture

\section{Cause and Effect Analysis}

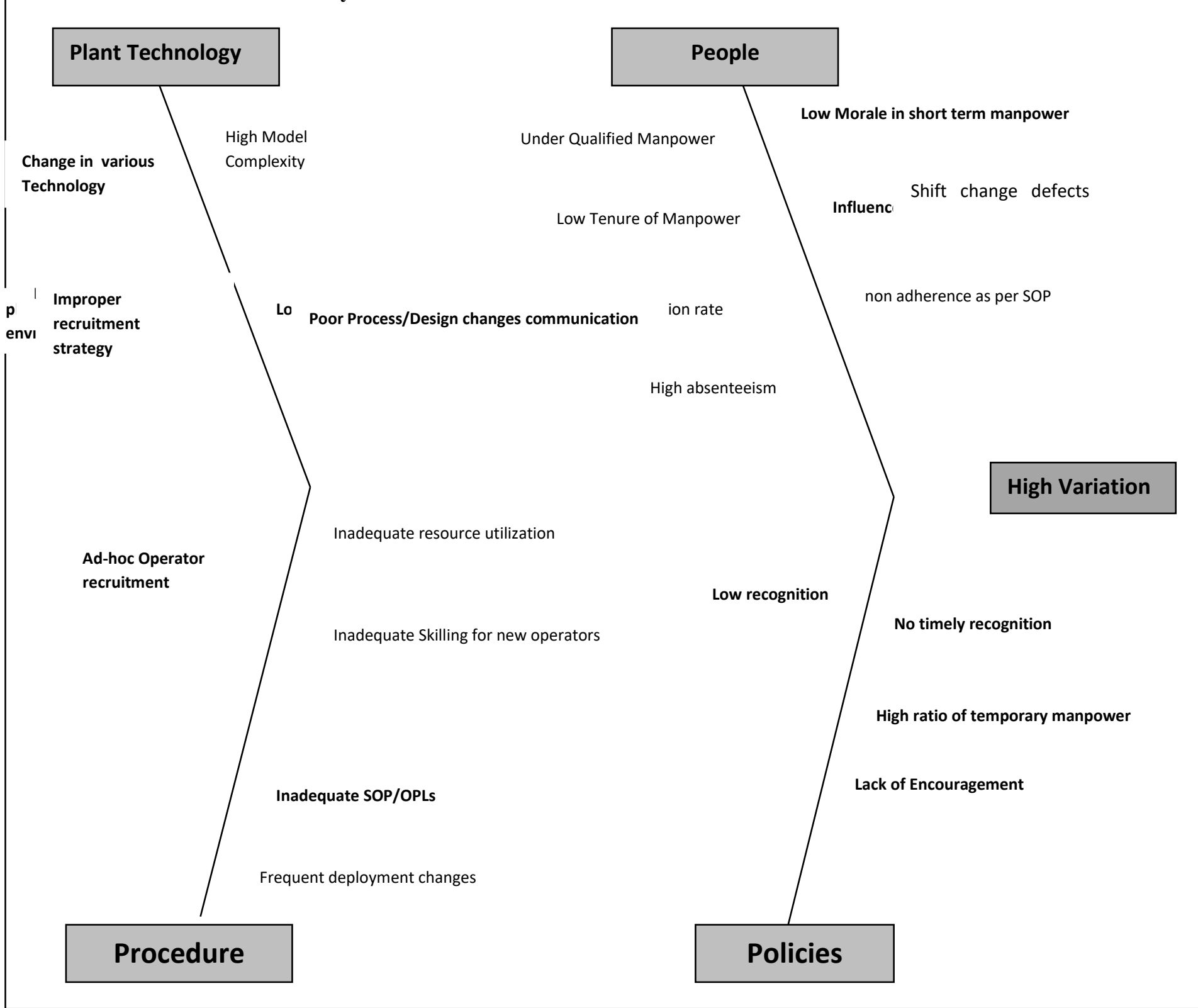

In above diagram we can easily identify Cause \& Effect (CE) matrix at the various level as highlighted in grey in the fish bone diagram the casuses and effects are been measured.Analysis is been recorded Policy implementation to plant technology .

Some critical observation can seen on $4 \mathrm{~m}$ conditions that is Man, machine, method, and Materials .which effects on the entire cycle of manufacturing .high variations are seen

1)Procedures are not sound, ad- hoc operator recruitment also turn to inadequate skilling of new operator .

2) Poor process frequently design changes and communication which turn to difficulty in following SOP 


\title{
International Advanced Research Journal in Science, Engineering and Technology
}

\author{
Vol. 8, Issue 9, September 2021
}

DOI: 10.17148/IARJSET.2021.8975

3) SOP deliberately not followed due low morale and under qualified manpower .

4) Change in various technology is been done, but very poor work environment, lack of encourage ment .

5) high model changeover is observed inadequate skilling of manpower is done .

All the causes has been tested on the various parameter there are many inherent challenges in the process the technical manpower ware in the category of experienced diploma, engineers and operators at work stations even though all three categories of operators were fully trained the higher qualified operators could handle the manufacturing process complexities in better way and generated much fewer defects

4) On the basis of this analysis the solutions for above problems states various conditions like .

1)Proper training to be provided job station related

For SOP , tools, safety aspects , critical Quality issues need to be attended on priority

Train the trainer workshop and trainer certification process need to be standardize . on the job training needs should also improved .

2) Higher qualification and experience workers need to recruit

In terms of all technical requirement proper qualification and experience of manpower need to be tested higher qualification and experience workmen need to hire to reduce the defects and to perform efficiently

3) Quality of work condition need to improve.

"SMART" manufacturing Training to impart so that operators get all manufacturing directory and holistic understanding in terms of technology, quality process engineering safety etc they should be equipped from all the direction to handle process complexities. Development is the need of hour it is also become key driver to address the issues like unemployment, improving productivity in facilitating sustainable enterprises

All of the above solutions brings importance of inherent training for workmen during their technical education the responsibility lies on the companies to reduce such defect in manufacturing process so the starts with training cell within their campus under CSR activity. CSR is strategic move of corporate they incorporates skill training frame work the Indian manufacturing industry to provide real life training opportunities in terms of promoting the brand ensure in assisting essential vocational training for the community is fast embracing the principles of TQM and world class manufacturing in country like India with huge work force employment and job creations are topmost focus companies like Telco, Bajaj, Suzuki some of the local vendors of Bajaj as Endurance (I) ltd and verroc(I)pvt ltd , are taking lead role to establish all such training centers to improve the quality of technical manpower . various skills are always need to upgrade changing manufacturing process to bridge this Gap the need is for a comprehensive skill development policy, industry relevant curriculum active collaboration between academia and industry and willing ness of industries to provide opportunities.

\section{CONCLUSION}

Globally the manufacturing industry is moving towards deskilling, day to day advance ment in various skills are emerging in technical and soft skills industry and employee has to face these differences at work process the customer need and global need to be assimilate in present work situation. The usage of automation in the growing exponently also the use of robots incoming up, But hugely populous country like India were generating employment is a foremost national issue. There should be judicious combination of utilization of operator skill as well as the deployment of right tools for preventing mistakes in mass manufacturing to meet the global quality.

\section{REFERENCES}

- $\quad$ National policy for skill development and enterprenurship,2015

- $\quad$ Ding, L Promote the employment from the corporate social responsibility(2010) .

- $\quad$ Majumdar, S Reflections on opportunities and challenges of skill development in India , (2016).

- Indian Journal of Research July December 2018 vol no 7 ISSN 2231-6655 research

development research foundation.

- Gupta,S \&Jain S.K. A literature review of lean manufacturing, international journal of management science $8(5) 241-250,(2013)$

- $\quad$ https://www.focus-economics .com /blog/the -largest-economies-in-the -world

- Journal of organization \&human behavior Volume 8 issue pg 66 july 2019

- $\quad$ Preparation for the world of work Springer's Wiesbaden. (pp.7-13)

- International journal for management and economics vol 1 no 29 .pg 140 to 145 .

- $\quad$ Tilak JGB (2006) Education -A saga of spectacular achievements and conspicuous failures , India social development .

- $\quad$ Report on higher education summit 2011 by FCCI INDIA Report pg 36

- Journal of organization and human behavior. vol 8 issue 2\&3 ISSN:2277-3274 